\title{
A critical review of recent developments in radiotherapy for non-small cell lung cancer

Sarah Baker ${ }^{1}$, Max Dahele ${ }^{2}$, Frank J. Lagerwaard ${ }^{2}$ and Suresh Senan ${ }^{2^{*}}$

\begin{abstract}
Lung cancer is the leading cause of cancer mortality, and radiotherapy plays a key role in both curative and palliative treatments for this disease. Recent advances include stereotactic ablative radiotherapy (SABR), which is now established as a curative-intent treatment option for patients with peripheral early-stage NSCLC who are medically inoperable, or at high risk for surgical complications. Improved delivery techniques have facilitated studies evaluating the role of SABR in oligometastatic NSCLC, and encouraged the use of high-technology radiotherapy in some palliative settings. Although outcomes in locally advanced NSCLC remain disappointing for many patients, future progress may come about from an improved understanding of disease biology and the development of radiotherapy approaches that further reduce normal tissue irradiation. At the moment, the benefits, if any, of radiotherapy technologies such as proton beam therapy remain unproven. This paper provides a critical review of selected aspects of modern radiotherapy for lung cancer, highlights the current limitations in our understanding and treatment approaches, and discuss future treatment strategies for NSCLC.

Keywords: Radiotherapy, Non-small cell lung cancer, Intensity-modulated radiotherapy, Stereotactic ablative radiotherapy, Proton therapy

Abbreviations: 2DRT, Two- dimensional radiotherapy; 3DCRT, Three- dimensional conformal radiotherapy; 4DCT, Fourdimensional computed tomography; BED, Biologically effective dose; CBCT, Cone beam computed tomography; COPD, Chronic obstructive pulmonary disease; CRT, Concurrent chemoradiotherapy; CT, Computed tomography; FDA, United States food and drug administration; FDG-PET/CT, Flurodeoxyglucose-positron emission tomography/ computed tomography; FEV1, Forced expiratory volume in $1 \mathrm{~s}$; GTV, Gross tumor volume; HR, Hazard ratio; IMPT, Intensity-modulated proton therapy; IMRT, Intensity-modulated radiotherapy; ITV, Internal target volume; MPLCs, Multiple primary lung cancers; MRI, Magnetic resonance imaging; NCDB, National cancer database; NSCLC, nonsmall cell lung cancer; OARs, Organs at risk; OS, Overall survival; PBT, Proton beam therapy; PFS, Progression-free survival; PROs, Patient-reported outcomes; PSPT, Passively scattered proton therapy; PTV, Planning target volume; QALY, Quality-adjusted life-year; QOL, Quality of life; RCT, Randomized controlled trial; RT, Radiotherapy; RTOG, Radiation therapy oncology group; SABR, Stereotactic ablative radiotherapy; SEER, Surveillance, epidemiology, and end results; TKI, Tyrosine kinase inhibitor; VATS, Video-assisted thoracoscopic surgery
\end{abstract}

\section{Background}

Lung cancer is the most frequently diagnosed cancer worldwide and the leading cause of cancer mortality, accounting for over 1.6 million deaths annually [1]. The role of curative-intent radiotherapy (RT) is well established in locally advanced [2] and early stage [3] nonsmall cell lung cancer (NSCLC). Nonetheless, the thorax

\footnotetext{
* Correspondence: s.senan@vumc.nl

${ }^{2}$ Department of Radiation Oncology, VU University Medical Center, De Boelelaan 1117, Postbox 70571007 MD Amsterdam, The Netherlands Full list of author information is available at the end of the article
}

remains a challenging anatomical site for RT delivery, due to the low electron density of lung, respiratory- and cardiac-induced tumor motion, and proximity of critical structures such as the esophagus and spinal cord. While advanced RT technologies can address many of these challenges [4-7], in most cases, the clinical benefit of such technology still needs to be demonstrated, especially since radiation oncology was the medical specialty generating the greatest increase in Medicare expenditures between 2003 and 2009 [8]. However, the evaluation of new technologies remains challenging. This review will discuss the 
current state of modern RT for NSCLC, limitations, and strategies to improve clinical outcomes in the future.

\section{Early stage, localized disease: lung SABR}

The impact of advanced RT technology is perhaps most evident in the setting of early-stage NSCLC. Stereotactic ablative radiotherapy (SABR) is now considered the standard of care for medically inoperable patients with peripheral early-stage NSCLC [3]. SABR utilizes small margins for positional uncertainty, facilitated by 4-dimensional computed tomography (4DCT), multiple conformal or intensity modulated beams or arcs and volumetric image-guidance [9]. While peripheral lung SABR can also be delivered without these technologies, newer techniques can increase treatment efficiency and user confidence. Treatment-related toxicity with peripheral lung SABR is modest [10-12]. As SABR is not universally available, it is reassuring that data from the randomized SPACE study in patients with peripheral NSCLC suggest similar tumor outcomes with conventionally fractionated 3-dimensional conformal radiotherapy to 70 Gy [13].

There is an ongoing debate about the role of SABR in patients who are fit to undergo surgery [9]. A pooled analysis of two randomized trials of operable patients which closed prematurely due to slow accrual, showed a $16 \%$ higher 3-year survival with SABR compared to surgery $(p=0.037)$. This was due to the higher rate of perioperative mortality in the surgical group [14]. A propensity score matched analysis revealed that rates of treatment associated mortality and severe toxicity were lower with SABR for stage I-II NSCLC than with lobectomy performed by minimally-invasive video-assisted thoracoscopic surgery (VATS) [15]. Data from both retrospective $[16,17]$ and prospective phase II studies of SABR suggest survival outcomes similar to surgery [12, 18]. Shared decision-making tools may assist operable patients and their clinicians to arrive at a management plan based on a patient's preferences and values $[19,20]$. The role of SABR in surgical patients continues to be examined in 3 studies (NCT02468024, NCT02629458, NCT01753414), with a fourth (VALOR study) due to open this year. Both the SABRTooth and STABLE-MATES trials focus on highrisk patients.

Further improvements in SABR outcomes may come from strategies to reduce the rates of local-regional and distant failure, and from technology improvements that facilitate SABR in challenging scenarios such as central tumors (Table 1).

\section{Recurrences}

Local failures following SABR include recurrences in the treated lesion or involved lobe, which are in the order of $9-20 \%$ at 5 years $[12,16]$. True rates of local control can be difficult to ascertain due to post treatment fibrosis, and radiologic changes can continue to evolve many years after treatment [21]. So-called 'high-risk features' on serial computed tomography (CT) scans may allow post-SABR fibrosis to be distinguished from local recurrence [22, 23] and image texture analysis merits investigation for the early identification of disease recurrence [24]. Radiological follow-up in accordance with ESMO guidelines may enable early identification of salvageable local/regional failures [25-27].

Regional lymph node failures have been observed in between $13-15 \%$ of SABR patients at 5 years $[12,16]$ which appears comparable to lobectomy [15, 28, 29]. The role of routine endoscopic mediastinal and hilar nodal staging in patients without suspicious findings on positron emission tomography (PET)-CT studies is currently the subject of prospective studies [NCT01786590; NCT02719847]. When isolated hilar or mediastinal nodal failures occur, salvage radiotherapy may be possible in more than $50 \%$ of patients, and appears well tolerated [30].

Approximately $20 \%$ of patients develop distant disease recurrence following SABR [31,32], which is once again similar to that observed after surgery. This suggests that systemic therapies could be of benefit in selected patients, although the recruitment of medically inoperable, elderly patients into studies exploring combined SABR and cytotoxic chemotherapy has proven to be challenging (NCT01300299).

\section{Central early-stage NSCLC}

The Advanced Radiation Technology Committee of the International Association for the Study of Lung Cancer (IASLC) has defined 'central tumors' as those located within $2 \mathrm{~cm}$ in all directions of any mediastinal critical structure, including the bronchial tree, esophagus, heart, brachial plexus, major vessels, spinal cord, phrenic nerve, and recurrent laryngeal nerve [33]. It is notable that severe toxicity was reported following delivery of SABR in 3 fractions to doses of 60-66 Gy to central tumors [34], but not when 'risk-adapted' dosing strategies were used [12]. Both a systematic review [35], and a recent update [36], suggest that risk-adapted SABR delivered in 8 fractions is an effective treatment for moderately central tumors. However, tumor location may help to explain some of the differences between reports. It is important to distinguish 'moderately central' tumors from lesions immediately adjacent to central airways, so-called 'ultracentral lesions' (Fig. 1). The latter term has been used to describe a PTV that overlaps the trachea or main bronchi [37], with increased toxicity reported for this subgroup after both conventional and hypo-fractionated radiotherapy schemes [37-39]. A retrospective study reported that likely or possibly treatmentrelated deaths occurred in $7.5 \%$ of patients with moderately central tumors [36]. The recent Radiation Therapy Oncology Group (RTOG) 0813 trial aimed to establish the 
Table 1 Challenges and solutions for difficult SABR scenarios

\begin{tabular}{|c|c|c|c|}
\hline \multicolumn{2}{|l|}{ Clinical scenario } & \multirow{2}{*}{$\begin{array}{l}\text { Challenges } \\
\text { Choice of SABR in operable NSCLC }\end{array}$} & \multirow[b]{2}{*}{$\begin{array}{l}\text { Potential solutions being explored } \\
\text { - Shared decision-making }[19,20] \\
\text { - Comparative effectiveness research (including patient-reported } \\
\text { outcomes, QOL and cost-effectiveness analyses) } \\
\text { with "big data" strategies to facilitate data mining } \\
\text { - RCTs underway (NCT02629458, NCT01753414, } \\
\text { NCT02468024, VALOR study) }\end{array}$} \\
\hline Pre Treatment & $\begin{array}{l}\text { Incorporating patient } \\
\text { preferences for treatment }\end{array}$ & & \\
\hline & Obtaining a diagnosis & $\begin{array}{l}\text { Risks of treating benign disease } \\
\text { Risks of biopsy in frail patients }\end{array}$ & $\begin{array}{l}\text { - Use validated models for cancer risk determination in a } \\
\text { given population [9] } \\
\text { - Explore blood biomarkers [123] }\end{array}$ \\
\hline \multirow[t]{2}{*}{ Treatment } & $\begin{array}{l}\text { Central tumors } \\
\text { Multiple primary } \\
\text { lung cancers }\end{array}$ & $\begin{array}{l}\text { Proximity to OARs } \\
\text { Uncertainty in OAR location } \\
\text { Uncertainly in OAR dose constraints }\end{array}$ & $\begin{array}{l}\text { - "Big data" strategies to establish more reliable OAR dose } \\
\text { constraints } \\
\text { - MRI-guided adaptive RT [44] } \\
\text { - Protons [41] }\end{array}$ \\
\hline & Oligometastases & $\begin{array}{l}\text { Higher pneumonitis risk } \\
\text { Identify molecular and clinical } \\
\text { characteristics of patients likely } \\
\text { to benefit from ablative local therapies } \\
\text { Optimize sequencing of RT and } \\
\text { new systemic treatments }\end{array}$ & - Phase I-II trials, as well as randomized trials \\
\hline \multirow[t]{2}{*}{ Follow-up } & Detection of recurrences & $\begin{array}{l}\text { Distinguishing post-RT fibrosis } \\
\text { vs recurrent disease }\end{array}$ & • Radiomic approaches [24] \\
\hline & Survivorship issues & $\begin{array}{l}\text { Loco-regional recurrences and } \\
\text { second lung tumors } \\
\text { Smoking cessation }\end{array}$ & $\begin{array}{l}\text { - Survivorship clinics [124] } \\
\text { - Patient-reported outcomes, including financial impact of } \\
\text { treatments }\end{array}$ \\
\hline
\end{tabular}

Abbreviations QOL quality of life, $R T$ radiotherapy, SABR stereotactic ablative radiotherapy, NSCLC non-small cell lung cancer, OAR organ at risk, PTV planning target volume

safest dose that can be delivered in 5 fractions for central lesions [40]. Preliminary data reported that patients treated with the highest dose level (60 Gy in 5 fractions) had a $23 \%$ rate of grade $3-5$ toxicity. It should be acknowledged that the true radiation tolerance for central organs at risk (OARs) remains unknown, and uncertainty in tumor and OAR positions during treatment adds to our inability to determine true cumulative doses.

It has been suggested that proton beam therapy (PBT) can allow for dose reduction to central structures [41], although the benefits of PBT may be questionable given its susceptibility to anatomic and positional variations [42]. Although on-line matched cone beam CT scans can be used to image OARs prior to irradiation [43], the field has been advanced by the recent introduction of magnetic resonance imaging (MRI) -guided RT delivery (MRIdian System, Viewray Inc, Cleveland, OH). The MRIdian platform facilitates online adaptive radiotherapy, and allows for direct tumor visualization during treatment delivery at 4 frames per seconds in the sagittal plane [44]. During gated radiotherapy using breath-hold mode, the system automatically shuts-off radiation delivery with a lag-time of $0.4 \mathrm{~s}$ (or less) when the target is outside pre-specified safety margins (Fig. 2). A number of other linac-MR delivery platforms are in development [45-47] and may contribute to advances in the practice of central SABR.

\section{Multiple primary lung cancers}

The incidence of multiple synchronous primary lung cancers (MPLCs) can be as high as 4-8 \% [48], and second primary lung cancers occur at a rate of approximately $3 \%$ per year [27]. Several studies report excellent local control and modest toxicity following SABR for MPLCs [49-51]. As larger volumes of some OAR's are irradiated in this situation, strategies designed to reduce tumor motion and dose to OARs are warranted.

\section{SABR and stage IV disease}

In a randomized trial, surgical resection of a single brain metastasis combined with whole brain RT, more than doubled median survival from 15 to 40 weeks, and lengthened functional independence compared to RT alone [52]. More than three-quarters of patients in the study by Patchell et al. consisted of patients with NSCLC. In unselected oligometastatic patients, however, rates of progression-free survival (PFS) are highly variable, suggesting that many have more widely disseminated occult disease. In retrospective studies, rates of 5-year survival may approach $50 \%$ in highly select patients, namely those with metachronous lesions, lower number of metastases and a good performance status [53]. A recent multi-centre phase II trial randomized NSCLC patients with $\leq 3$ metastases who did not progress after first line systemic treatment to either local consolidative therapy (surgery, RT or chemo-RT to all metastases, 

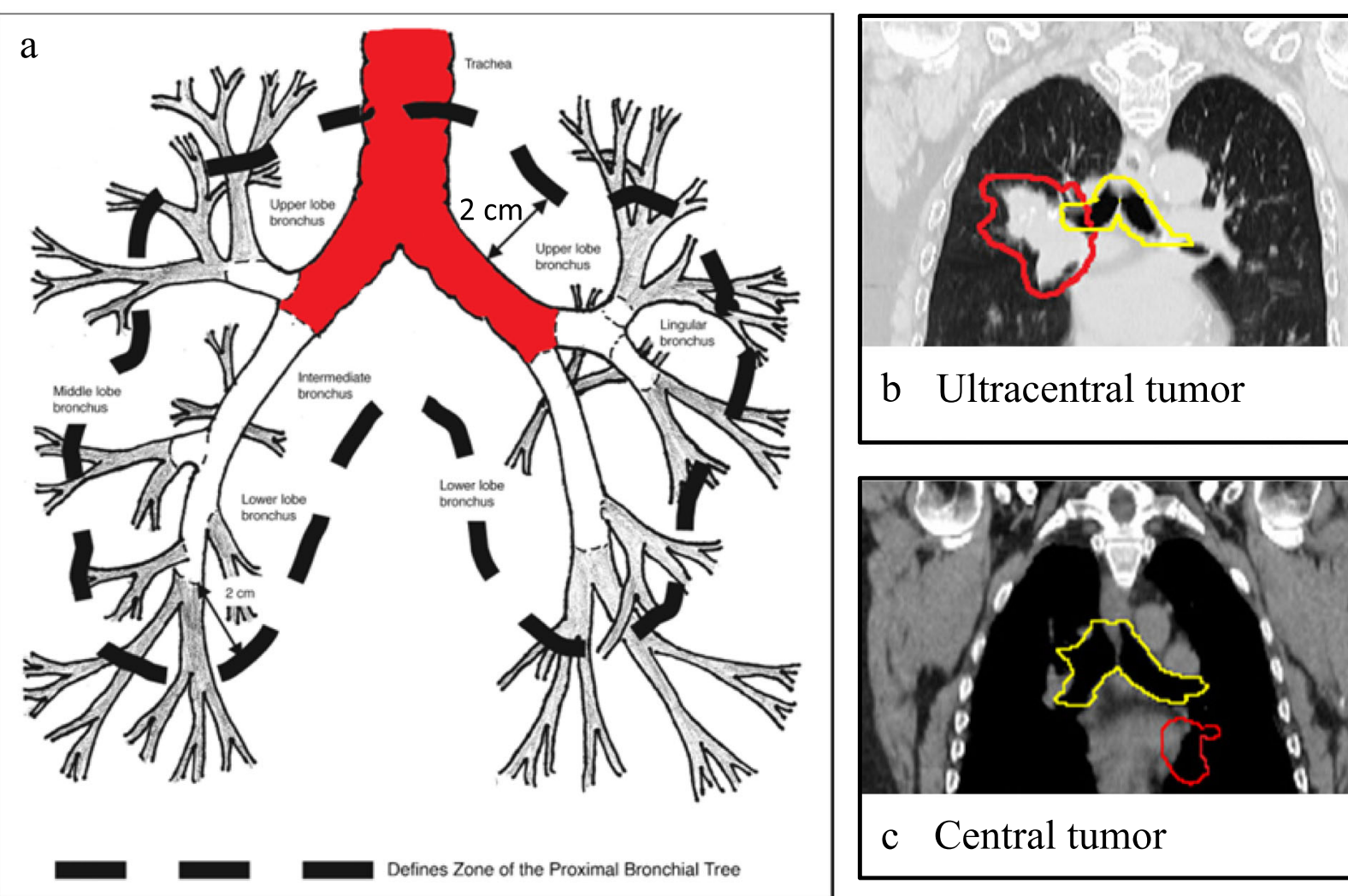

b Ultracentral tumor

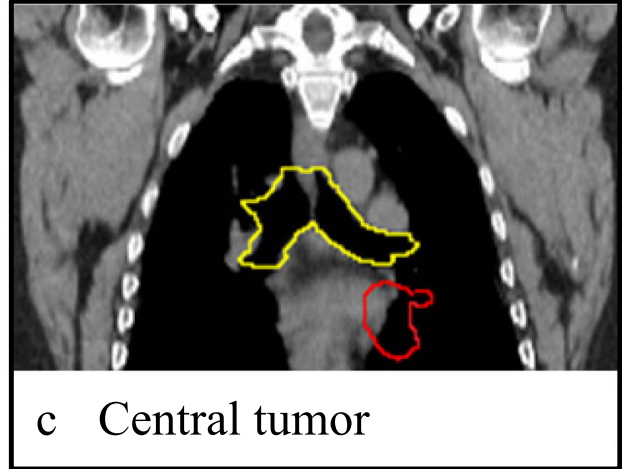

Fig. 1 Definitions and examples of central and ultra-central lung tumors. a Diagram of the central airways of the lung. Reprinted with permission. (c)2006. American Society of Clinical Oncology. All rights reserved. Timmerman, R et al.: J Clin Oncol 24(30), 2006: 4833-9. The black dashed line defines the location of tumors that are central relative to the proximal bronchial tree. The term central has been widened to include the region within $2 \mathrm{~cm}$ in all directions of any mediastinal critical structure, including the bronchial tree/trachea, esophagus, heart, brachial plexus, major vessels, spinal cord, phrenic nerve, and recurrent laryngeal nerve. The region shaded red shows the trachea and main bronchi, and lesions with a PTV which overlaps \this region are considered as ultracentral. b Example of an ultracentral tumor (planning target volume in red, and main bronchi/trachea in yellow). c Example of a central tumor

with or without systemic therapy) or to systemic therapy alone [54]. The study was closed early after only 49 patients were enrolled when interim analysis found the median PFS in the consolidative therapy arm to be 14.4 months compared to 3.9 months in standard arm. Although these findings are provocative, the limited patient numbers mean that additional studies will be required. The interest in exploring ablative treatments for oligometastatic disease will increase following the proposed revision in the 8th Edition of the TNM lung cancer classification system, where the current M1b category is subdivided into a new M1b, comprising a single extra-thoracic metastasis in a single organ, and M1c, encompassing multiple extra-thoracic metastases [55].

Another area of investigation is the use of SABR in the setting of oligo-progression, where disease that has initially responded to systemic treatment, subsequently demonstrates limited progression [56]. In patients with stage IV disease who receive molecular targeted therapy for an activating mutation of the EGFR receptor, or an ALK- translocation, and who subsequently develop progression at limited sites, the use of local ablative therapies is now recommended in the European Society for Medical Oncology (ESMO) guidelines [57].

\section{Locally advanced NSCLC}

Stage III NSCLC remains a challenging disease to treat. In randomized trials, the addition of surgery has not been shown to be of benefit to overall survival (OS), compared to definitive concurrent chemoradiotherapy (CRT) (Table 2). In a phase III trial of concurrent CRT, radiation dose escalation to 74 Gy had a detrimental effect on survival [58]. Rates of local and distant failure after CRT have remained constant over time (approximately 30-40 and 40-50\%, respectively) however median OS has improved modestly, by approximately 10 months (Table 3). The reasons for this improvement in OS are uncertain, but stage migration due to improved imaging may be one contributory factor [59]. In addition, the incidence of high-grade radiation pneumonitis and esophagitis has decreased significantly in the past decade [60]. 

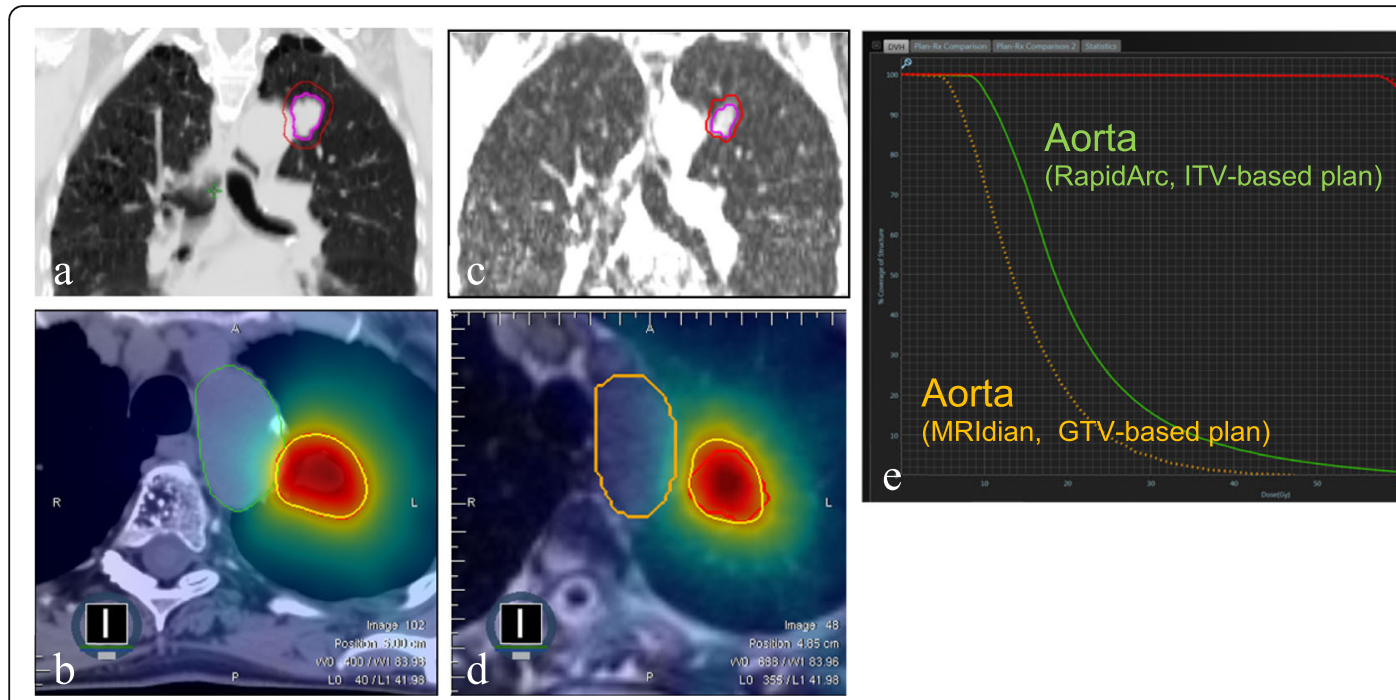

\section{(RapidArc, ITV-based plan}

Fig. 2 Comparative treatment plans for MRI-guided radiotherapy using breath-hold versus a standard free-breathing internal target volume (ITV)-based approach for a central tumor in a patient with interstitial lung disease. Panel a shows the ITV (7.8 cc) for a RapidArc (volumetric modulated arc therapy) plan, to which a $5 \mathrm{~mm}$ margin was added to derive a planning target volume (PTV, $26 \mathrm{cc}$ ); panel $\mathbf{b}$ the corresponding dose color-wash for an 8 fraction stereotactic ablative radiotherapy scheme to $60 \mathrm{~Gy}$. Treatment was delivered using on-line MRI guided breath-hold on the MRIdian in which the target was the gross tumor volume ( $6.9 \mathrm{cc}$, Panel $\mathbf{c})$, to which a $3 \mathrm{~mm}$ setup PTV margin was added (PTV $13.6 \mathrm{cc})$. Panel $\mathbf{d}$ shows the MRldian dose color-wash, and Panel $\mathbf{e}$ the dose volume histograms for the adjacent aorta for both plans

Survival improvements may also reflect the availability of effective systemic therapies for the $50 \%$ of patients who relapse with systemic disease [61], although the use of such therapies is not routinely captured in trials.

Currently, ESMO recommends conventionally fractionated CRT to 60-66 Gy, with two to four concomitant cycles of chemotherapy to treat locally advanced NSCLC, with no evidence for induction or consolidation chemotherapy [2]. In patients unfit for concurrent CRT, accelerated RT delivery is suggested. In practice, significant numbers of patients are not fit to undergo CRT; $20 \%$ or more of patients with stage IIIA receive only palliative treatment, with another $12 \%$ receiving RT as a single modality [62]. In patients eligible only for RT, image-guided hypofractionated RT is a strategy that merits investigation, although it should be acknowledged that competing causes of mortality in such patients may limit major improvements in OS.

\section{Post-operative RT}

The role of post-operative RT (PORT) in patients with completely resected N2 disease remains unclear [63]. An earlier meta-analysis using older radiotherapy techniques failed to show a survival benefit for this patient group [64]. More recent population studies have suggested a survival benefit with PORT for pN2 disease $[65,66]$. However, pre-operative mediastinal lymph node staging has improved significantly in the past decade, with the use of FDG-PET scans and endoscopic staging, resulting in $\mathrm{N} 2$ disease that is discovered only at the time of surgery being a less common scenario.
Definitive conclusions of the role of PORT in N2 disease must await the results of an ongoing phase III trial, in which both surgical procedures and RT techniques are clearly specified (LungART, NCT00410683).

\section{Have newer RT technologies improved survival in stage III NSCLC?}

A number of innovations in RT have been introduced in the past two decades [67]. The replacement of conventional treatment simulation with CT simulation has been associated with a survival advantage in the SEER population [6]. Guidelines now recommend 4DCT simulation, and cone beam CT (CBCT) for image-guidance which has reduced planning target volume (PTV) margins [68]. More accurate dose calculation algorithms are in clinical use [4], and more conformal radiation delivery can be achieved with intensity-modulated RT (IMRT) and PBT $[7,69]$. Improved OAR sparing with more conformal dose distributions, and on-line image-guidance, may have contributed to the approximately $10 \%$ reduction in acute esophagitis rates seen in recent years (Table 2).

\section{Intensity-modulated RT}

Planning studies have consistently demonstrated gains with IMRT compared with 3- dimensional conformal RT (3DCRT), for metrics including mean lung dose, lung V20, spinal cord dose, and heart doses [7, 70]. However volumes of low-dose irradiation may increase with some IMRT delivery approaches [71] (Fig. 3). IMRT has been rapidly adopted for lung cancer despite a paucity of evidence [72]. 
Table 2 Outcomes from randomized trials with a surgical arm in stage III non-small cell lung cancer

\begin{tabular}{|c|c|c|c|c|c|c|c|c|c|}
\hline Trial & Inclusion & $\begin{array}{l}\text { Staging PET } \\
\text { or PET/CT }\end{array}$ & Study question & $\mathrm{RT}^{\mathrm{a}}$ & Chemotherapy & N (randomized) & Answer & Treatment related mortality & $\begin{array}{l}5 \text {-year } \\
\text { OS }\end{array}$ \\
\hline $\begin{array}{l}\text { EORTC } 08941 \\
{[125]}\end{array}$ & $\begin{array}{l}\text { Unresectable } \\
\text { IIIA (N2) }\end{array}$ & $\begin{array}{l}\text { Not } \\
\text { mandatory }\end{array}$ & CT-S vs CT-RT & $\begin{array}{l}\text { 60-62.5 Gy to primary } \\
\text { and involved mediastinum; } \\
40-46 \text { Gy to uninvolved } \\
\text { mediastinum }\end{array}$ & $\begin{array}{l}\text { Platinum-based } \\
\text { with at least one } \\
\text { other agent }\end{array}$ & 332 & $\begin{array}{l}\text { No significant } \\
\text { difference }\end{array}$ & $\begin{array}{l}4 \% \text { within } 30 \text { days of surgery } \\
1 \text { patient died of RP, timing NR }\end{array}$ & $\begin{array}{l}16 \% \\
14 \%\end{array}$ \\
\hline $\begin{array}{l}\text { INT } 0139^{b} \\
{[126]}\end{array}$ & $\begin{array}{l}\text { Potentially } \\
\text { resectable } \\
\text { IIIA (N2) }\end{array}$ & $\begin{array}{l}\text { Not } \\
\text { mandatory }\end{array}$ & CRT-S vs CRT & $\begin{array}{l}45 \text { Gy in CRT-S arm } \\
61 \text { Gy in CRT arm }\end{array}$ & Cisplatin-etoposide & $\begin{array}{l}429 \text { (396 } \\
\text { eligible) }\end{array}$ & $\begin{array}{l}\text { No significant } \\
\text { difference }\end{array}$ & $\begin{array}{l}8 \% \\
2 \% \\
\text { (No deaths during induction) }\end{array}$ & $\begin{array}{l}27 \% \\
20 \%\end{array}$ \\
\hline $\begin{array}{l}\text { ESPATUE }^{C} \\
{[127]}\end{array}$ & $\begin{array}{l}\text { Resectable } \\
\text { IIIA (N2) and } \\
\text { selected IIIB }\end{array}$ & $97 \%$ & $\begin{array}{l}\text { CT-CRT-S vs } \\
\text { CT-CRT-CRTboost }\end{array}$ & $\begin{array}{l}\text { Both arms: } \\
\text { induction } 45 \text { Gy delivered } \\
\text { as } 1.5 \text { Gy BID } \\
\text { In definitive CRT arm: } \\
\text { risk-adapted CRTboost to } \\
65-71 \text { Gy }\end{array}$ & $\begin{array}{l}\text { Induction: } \\
\text { cisplatin-paclitaxel } \\
\text { Concurrent: } \\
\text { cisplatin-vinorelbine }\end{array}$ & 161 & $\begin{array}{l}\text { No significant } \\
\text { difference, but } \\
\text { closed early and } \\
\text { was under- powered } \\
\text { with respect to the } \\
\text { primary end-point } \\
\text { of OS }\end{array}$ & $\begin{array}{l}6 \% \text { in surgical arm } \\
3 \% \text { in definitive CRT arm } \\
\text { ( } 2 \text { additional patients died during } \\
\text { induction) }\end{array}$ & $\begin{array}{l}44 \% \\
40 \%\end{array}$ \\
\hline $\begin{array}{l}\text { SAKK } 16 / 00 \\
{[128]}\end{array}$ & $\begin{array}{l}\text { Resectable } \\
\text { IIIA (N2) }\end{array}$ & $\begin{array}{l}\text { Required } \\
\text { (rate NR) }\end{array}$ & CT-RT-S vs CT-S & $\begin{array}{l}44 \text { Gy (in } 22 \text { fractions } \\
\text { over } 3 \text { weeks) }\end{array}$ & Cisplatin-docetaxel & 232 & No difference & $\begin{array}{l}0 \% \text { within } 30 \text { days of surgery } \\
3 \% \text { within } 30 \text { days of surgery }\end{array}$ & $\begin{array}{l}40 \% \\
34 \%\end{array}$ \\
\hline
\end{tabular}

Courtesy of Prof. Rafal Dziadziuszko. Discussant ESMO 2014 Madrid. Modified to update subsequent publication

CT induction chemotherapy, CRT concurrent chemoradiotherapy, RT radiotherapy; $S$ surgery, CRTboost concurrent chemoradiotherapy boost, $R P$ radiation pneumonitis, NR not reported, BID twice daily, OS overall survival

${ }^{a}$ RT doses in standard fractionation unless otherwise indicated

${ }^{\mathrm{b}}$ Increased disease-free survival in surgery arm (12.8 vs 10.5 months; $p=0.017$ ); unplanned analysis showed longer median OS in lobectomy subgroup vs matched CRT subgroup (33.6 vs 21.7 months; $p=0.002$ ) ${ }^{\prime} 246$ enrolled (out of 500 planned). After induction treatment, patients with resectable tumors $(n=161,65 \%)$ randomized. In all 246 patients, 5 year OS $34 \%$ 
Table 3 Outcomes with definitive chemoradiotherapy for stage III non-small cell lung cancer

\begin{tabular}{|c|c|c|c|c|c|c|c|c|c|}
\hline Trial & Inclusion & $\begin{array}{l}\text { Staging } \\
\text { PET-CT }\end{array}$ & Histology & $\begin{array}{l}\text { Treatment regimen in } \\
\text { standard CRT arm }\end{array}$ & RT technique & $N$ & PTV (mean) & $\begin{array}{l}\text { Toxicity in standard } \\
\text { CRT arm }\end{array}$ & Outcomes \\
\hline $\begin{array}{l}\text { RTOG } 0617 \\
{[58]}\end{array}$ & Unresectable III & $91 \%$ & $\begin{array}{l}42 / 47 \% \\
\text { squamous } \\
\text { in 60/74 Gy } \\
\text { arms }\end{array}$ & $\begin{array}{l}60 \text { Gy } \\
\text { Concurrent } \\
\text { carboplatin-paclitaxel, } \\
\text { followed by } 2 \text { cycles } \\
\text { consolidation }\end{array}$ & $\begin{array}{l}46 / 47 \% \text { IMRT } \\
\text { in 60/74 Gy arms } \\
\text { (Remainder 3DCRT) }\end{array}$ & $\begin{array}{l}424 \text { analyzable } \\
\text { for radiation } \\
\text { end-point }\end{array}$ & $\begin{array}{l}495 / 510 \mathrm{~mL} \\
\text { in the } 60 / \\
74 \\
\text { Gy arm }\end{array}$ & $\begin{array}{l}\text { In } 60 \text { Gy arm: } \\
\text { Grade } \geq 3 \text { RP } 7 \% \\
\text { Grade } \geq 3 \\
\text { esophagitis } 7 \% \\
\text { Grade } 5 \text { toxicity } 3 \%\end{array}$ & $\begin{array}{l}\text { In } 60 \text { Gy arm: } \\
\text { Median OS } \\
29 \text { months } \\
\text { 2-year OS } 58 \% \\
\text { 2-year LF } 31 \% \\
\text { 2-year DF } 47 \%\end{array}$ \\
\hline $\begin{array}{l}\text { PROCLAIM } \\
{[78]}\end{array}$ & Nonsquamous III & $82 \%$ & $\begin{array}{l}\text { Non-squamous } \\
\text { only }\end{array}$ & $\begin{array}{l}60-66 \text { Gy } \\
\text { Arm A: } \\
\text { pemetrexed-cisplatin, } \\
\text { pemetrexed consolidation } \\
\text { Arm B: etoposide-cisplatin, } \\
\text { non-pemetrexed } \\
\text { consolidation }\end{array}$ & $\begin{array}{l}25 \% \text { IMRT } \\
\text { (Remainder 3DCRT) }\end{array}$ & 598 & $607 / 585 \mathrm{~mL}$ & $\begin{array}{l}\text { Grade } \geq 3 \text { RP } \\
1.8 / 2.6 \% \\
\text { Grade } \geq 3 \text { esophagitis } \\
15.5 / 20.6 \% \\
\text { Grade } 5 \text { toxicity } \\
1.7 / 1 \%\end{array}$ & $\begin{array}{l}\text { Median OS } 27 / 25 \\
\text { months } \\
\text { Median PFS } \\
11.4 / 9.8 \text { months } \\
\text { IFF (site of } 1^{\text {st }} \text { failure) } \\
42 \% \\
\text { DF (site of } 1^{\text {st }} \\
\text { failure) } 48 \%\end{array}$ \\
\hline $\begin{array}{l}\text { KCSG-LU05-04 } \\
{[79]}\end{array}$ & Unresectable III & $92 \%$ & $\begin{array}{l}32 \% \\
\text { squamous }\end{array}$ & $\begin{array}{l}66 \text { Gy } \\
\text { Concurrent } \\
\text { docetaxel-cisplatin } \\
\text { Arm A: CRT-observation } \\
\text { Arm B: CRT-docetaxel- } \\
\text { cisplatin consolidation }\end{array}$ & NR & 437 eligible & NR & $\begin{array}{l}\text { Grade } \geq 3 \text { RP } 1.2 \% \\
\text { Grade } \geq 3 \\
\text { esophagitis } \\
9.5 \% \\
\text { Grade } 5 \text { toxicity } 3.6 \% \\
\text { during CRT, } 2.9 \% \\
\text { during consolidation }\end{array}$ & $\begin{array}{l}\text { Median OS 20.6/ } \\
21.8 \\
\text { months } \\
\text { Median PFS 8.1/9.1 } \\
\text { months } \\
\text { After median } \\
\text { follow-up time of } \\
51 \\
\text { months: } \\
\text { DF } 25 \% \\
\text { LRR } 25 \% \\
\text { DF and LF } 3 \%\end{array}$ \\
\hline $\begin{array}{l}\text { RTOG } 9410 \\
\text { [129] }\end{array}$ & $\begin{array}{l}\text { Inoperable } \\
\text { stage ||-||| }\end{array}$ & $0 \%$ & $\begin{array}{l}38 \% \\
\text { squamous }\end{array}$ & $\begin{array}{l}63 \text { Gy } \\
\text { Cisplatin-Vinblastine }\end{array}$ & 2DRT & 610 & N/A & $\begin{array}{l}\text { For CRT with early } \\
\text { RT arm: } \\
\text { Grade } \geq 3 \text { esophagitis } \\
22 \% \\
\text { Grade } \geq 3 \text { acute RP } 4 \% \\
\text { Grade } 5 \text { toxicity } 2 \% \\
\text { (as worst overall toxicity) }\end{array}$ & $\begin{array}{l}\text { For CRT with early } \\
\text { RT arm: } \\
5 \text {-year OS } 16 \% \\
\text { Median OS } 17 \\
\text { months } \\
\text { IFF only } 25 \% \\
\text { Out of field only } \\
37 \% \\
\text { Both IFF and out } \\
\text { of field } 10 \%\end{array}$ \\
\hline $\begin{array}{l}\text { Meta-analysis of } 6 \\
\text { trials comparing } \\
\text { CRT vs sequential } \\
\text { CT/RT [130] }\end{array}$ & $\begin{array}{l}\text { Unresected } \\
\text { stage III }\end{array}$ & $0 \%$ & $46 \%$ & $\begin{array}{l}60 \mathrm{~Gy} \text { ( } 2 \text { trials), } 66 \mathrm{~Gy} \text {, } \\
\text { ( } 1 \text { trial), } 66 \mathrm{~Gy} \text { in } 24 \text { fractions } \\
\text { ( } 1 \text { trial), } 56 \mathrm{~Gy} \text { split course } \\
\text { (1 trial), } 48.5 \mathrm{~Gy} \text { (split course } \\
\text { of } 36 \mathrm{~Gy} \text { in } 12 \text { fractions, } 7 \\
\text { days rest, } 12.5 \mathrm{~Gy} \text { in } 5 \text { fractions) } \\
\text { Single agent low-dose cisplatin } \\
\text { (2 trials), cisplatin-based doublet } \\
\text { ( } 3 \text { trials), carboplatin (1 trials) }\end{array}$ & $\begin{array}{l}\text { 3DCRT in } 1 \text { trial } \\
\text { Remainder 2DRT }\end{array}$ & $\begin{array}{l}603 / 602 \text { in } \\
\text { concurrent/ } \\
\text { sequential } \\
\text { groups }\end{array}$ & N/A & $\begin{array}{l}\text { Grade } \geq 3 \text { esophagitis } \\
18 \% \text { (concurrent CRT) } \\
\text { Rates of acute RP and } \\
\text { Grade } 5 \text { toxicity NR }\end{array}$ & $\begin{array}{l}\text { For concurrent } \\
\text { CRT patients: } \\
\text { 3-year OS } 24 \% \\
\text { 5-year OS } 15 \% \\
\text { 3-year LRF } 28 \% \\
\text { 5-year LRF } 29 \% \\
\text { 3-year DF } 40 \% \\
\text { 5-year DF } 41 \%\end{array}$ \\
\hline
\end{tabular}

Abbreviations CRT chemoradiotherapy, CT chemotherapy, RT radiotherapy, IMRT intensity modulated radiotherapy, PTV planning target volume, $m L$ milliliters, $N / A$ not applicable, $R P$ radiation pneumonitis, OS overall survival, $D F S$ disease free survival, IFF in-field failure, $L F$ local failure, $D F$ distant failure, $L R R$ locoregional recurrence, $N R$ not reported, 3DCRT three- dimensional conformal radiotherapy, $2 D R T$ two-dimensional radiotherapy ${ }^{\mathrm{a} A l l}$ RT standard fractionation 


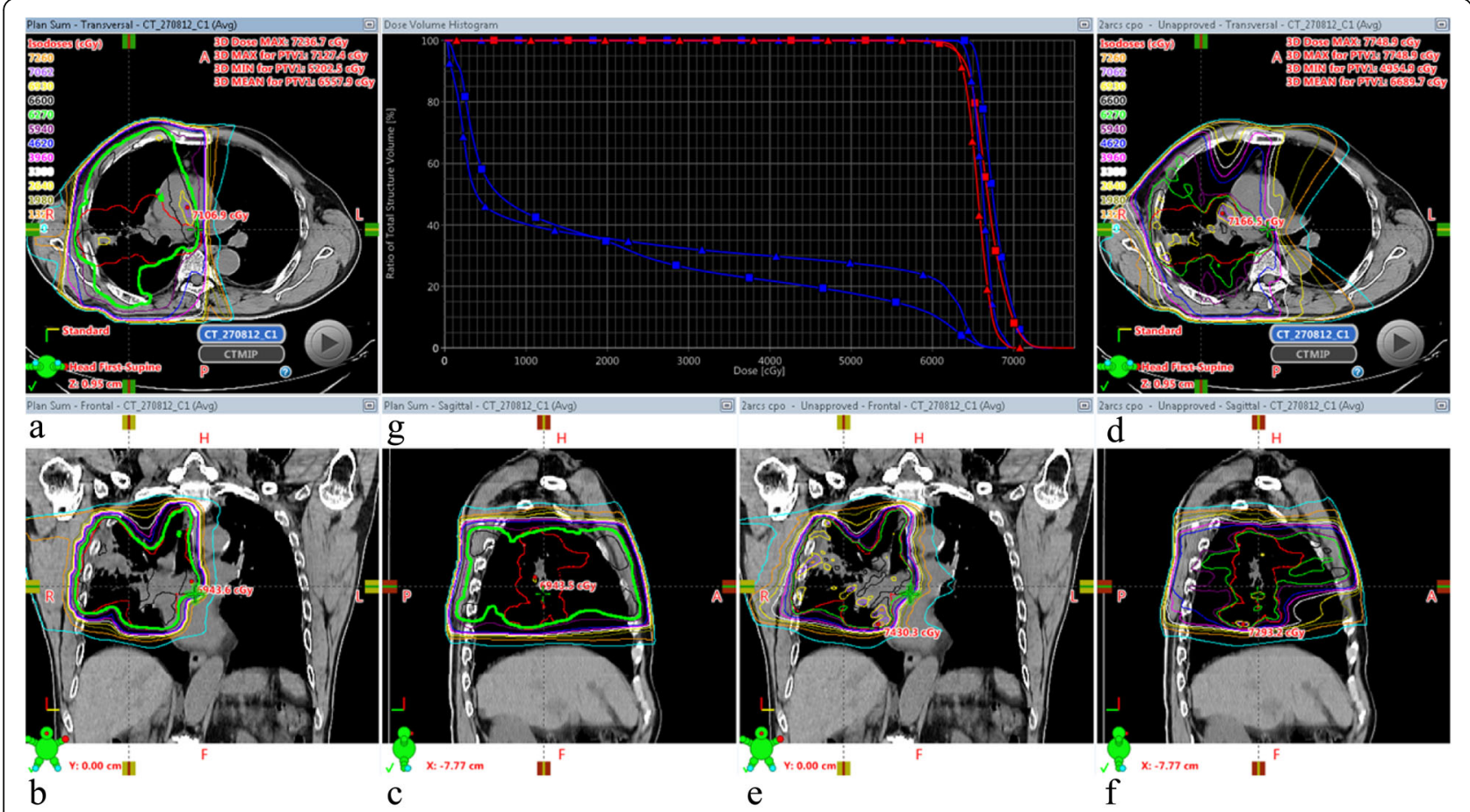

Fig. 3 A comparison of two radiotherapy techniques delivering 66 Gy in 33 fractions to a locally-advanced lung tumor. Panels a-c show axial, coronal, and sagittal views of a hybrid-intensity-modulated radiotherapy (IMRT) plan; panels $\mathbf{d}$-f $\mathbf{f}$ show the corresponding views of a volumetric modulated arc therapy (VMAT) plan for the same tumor. Panel $\mathbf{g}$ shows the dose-volume histogram of the hybrid IMRT plan (triangles) and VMAT plan (squares); the red and blue lines to the right represent the planning target volume (PTV) and internal target volume (ITV) respectively; the remaining pair of blue lines represent the lung volume (lung tissue outside the PTV). PTV and ITV coverage is comparable for both techniques (g). The VMAT plan has a more conformal $95 \%$ isodose (green line) around the PTV (d-f compared with a-c), however the maximum dose in the PTV is higher (g). The amount of lung receiving $\leq 20$ Gy is very similar with both techniques $(\mathbf{g})$, but the VMAT plan has a lower mean lung dose (19.5 Gy vs 22 Gy with hybrid-IMRT) and the hybrid-IMRT plan has more contralateral lung sparing, as seen by the position of low-dose isodose lines (orange [1320 cGy] and light blue [660 cGy])

A SEER analysis suggested that the main predictors of IMRT utilization were geographical location, and freestanding versus hospital-based center, rather than disease factors such as tumor size or stage [73]. Most comparisons of IMRT and 3DCRT for locally advanced NSCLC come from retrospective single-institution and registry-based analyses, all with well-recognized limitations. A National Cancer Data Base (NCDB) analysis found that the use of 3DCRT or IMRT improved survival in stage III patients, versus those treated with CRT using 2-dimensional RT(2DRT) [74]. However, when 3DCRT and IMRT were evaluated separately, there was no added survival with IMRT. Other analyses have also reported no survival or toxicity improvement with IMRT $[73,75,76]$, although these studies were conducted across heterogeneous patient groups. It is possible that the gains from IMRT are limited to specific patient groups, and another NCDB analysis suggested improved median and 5-year survival with IMRT for T3 and T4 tumors [77]. Unfortunately, many databases lack the comprehensive clinical and dosimetric data necessary to study the nature of the relationship between technology and outcomes.

It is notable that in recent trials in which half or more of patients were treated with $3 \mathrm{DCRT}$, the rates of grade $\geq 3$ pneumonitis following doses of up to $66 \mathrm{~Gy}$, were only in the range of $1.2-7 \%[58,78,79]$. Data from the recent RTOG 0617 dose escalation study merit closer inspection [58]. Approximately equal numbers of patients were treated with 3DCRT or IMRT contemporaneously, avoiding the confounding time factor present in retrospective analyses. Despite the IMRT group having a mean PTV about $15 \%$ larger and more stage IIIB tumors, rates of grade $\geq 3$ pneumonitis were reduced from 7.9 to $3.5 \%$. Furthermore, the IMRT cohort was more likely to receive full-dose consolidative chemotherapy [7], and reported less decline in quality of life at 12 months [80]. However, patients treated at higher accruing centers experienced a striking $10 \%$ survival advantage at 2 years [81]. These centers had higher rates of IMRT utilization, which was not independently predictive of survival, raising the question of whether the benefits attributed to IMRT in earlier analyses were in fact due to other, unrecognized factors associated with treatment at high accruing centers. Although the heart V5 and V30 were reported as predictive of survival in RTOG 0617, the lung dose, a well-recognized predictor of severe toxicity, was not included in the multivariate analysis. A subsequent analysis in an independent cohort found mean lung dose, but not 
heart doses, to be predictive of survival; there was a strong correlation between mean heart dose and heart V5 with the mean lung dose [82].

A number of groups are investigating if the IMRT delivery of higher doses to tumor regions that show high or persistent ${ }^{18} \mathrm{~F}$-flurodeoxyglucose (FDG)-PET uptake, will lead to improved survival [NCT01024829; NCT02788461; NCT01507428; NCT02790190]. A common underlying hypothesis for these trials is that local relapses may be more frequent in the high FDG uptake regions of primary tumors. Outcomes of the ongoing trials are awaited.

\section{Proton beam therapy}

Facilities for PBT have grown rapidly in recent years, even though limited data exists for its cost-effectiveness in NSCLC [83, 84]. Highly conformal high dose distributions can theoretically be achieved, allowing for further reduction in doses to normal structures compared to IMRT $[69,85]$. PBT is currently delivered either in passively scattered proton therapy (PSPT) mode, or pencil-beam scanning (PBS), which can deliver intensity-modulated proton therapy (IMPT). Planning studies have suggested that PBS can allow greater sparing of critical structures than PSPT $[86,87]$, but it may be more sensitive to changes in position or anatomy $[41,88]$.

A single-institution retrospective comparison of three treatment techniques (3DCRT, IMRT and PSPT) in locally advanced NSCLC, reported that proton delivery resulted in lower rates of grade 3 or higher pneumonitis and esophagitis ( 2 and $5 \%$, respectively; 3DCRT, 30 and $18 \%$; IMRT, 9 and $44 \% ; p<0.01$ for all) [89]. However, the rates of esophagitis are inconsistent with findings observed in recent phase III studies. A prospective randomized trial led by the MD Anderson Cancer Center compared photon IMRT versus PSPT, and reported no differences in treatment failures, which were defined as either grade $\geq 3$ pneumonitis or local failure at 1 year [90,91]. A second phase III trial with a target accrual of 560 stage II-IIIB NSCLC patients is now underway (RTOG 1308). Both PSPT and PBS are still permitted in this study. While the improved OAR sparing with PBT makes it a seemingly attractive option for treating large tumors, a large volume has consistently been associated with poorer survival [92-94], which suggests that survival gains may be modest, at best. There is, therefore, currently no high-level evidence to support the routine use of proton therapy in locally advanced NSCLC, and evidence supporting IMRT is based on population-based analysis of patient sub-groups. 3DCRT therefore remains an important treatment option, especially as access to radiotherapy is limited in many countries, and escalating costs are of concern [95, 96].

\section{Radiation and immunity}

RT can have an immune stimulatory effect by generating tumor antigens, promoting a T-cell mediated anti-tumor response, and potentially causing immune-mediated abscopal effects where distant non-target lesions can regress [97] (Fig. 4). However, abscopal effects are very uncommon [98].

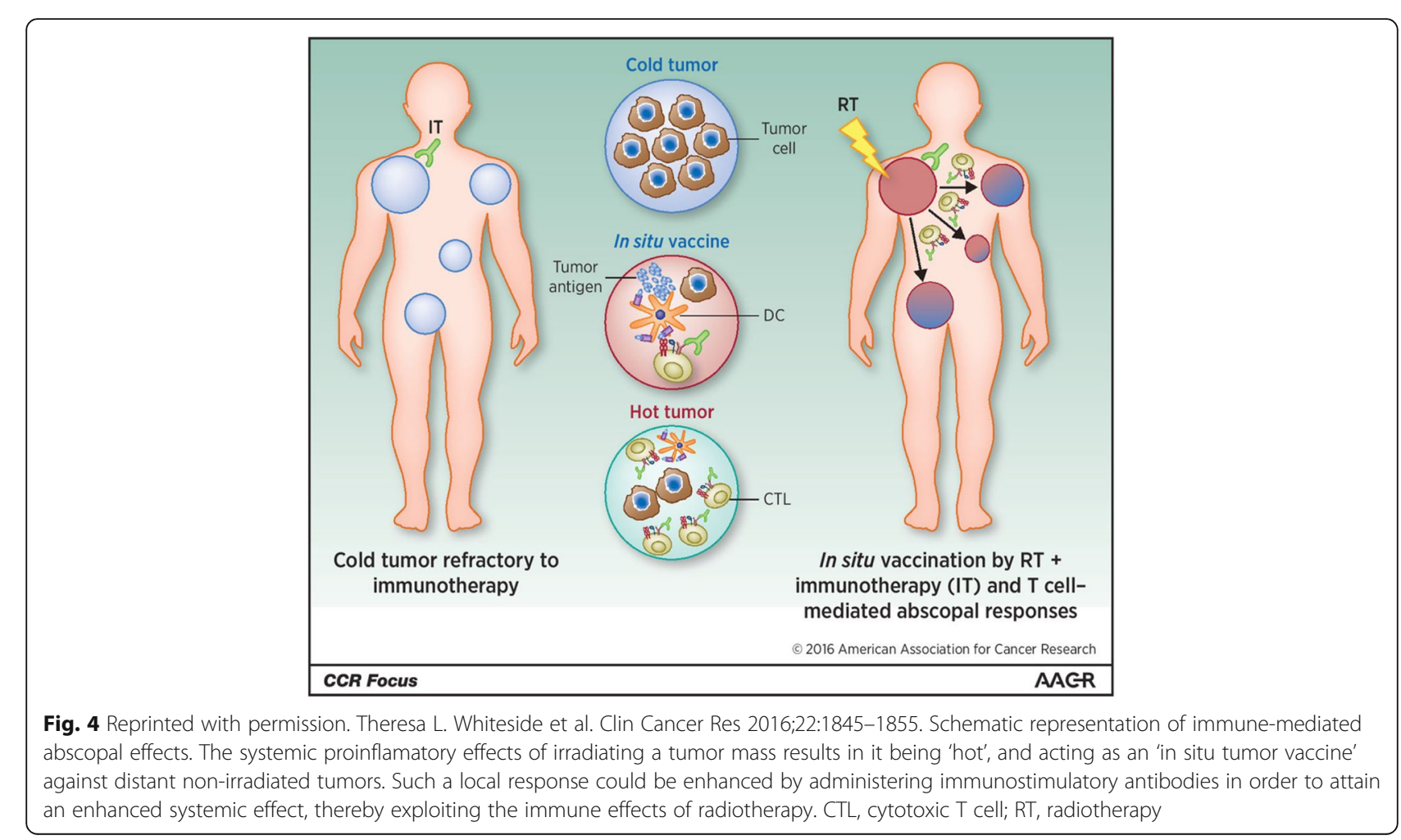


Radio-immunotherapy is a field of active research, and much remains unknown regarding the optimal sequencing of treatments, as well as optimal RT dose/fractionation schedules $[99,100]$. Some data suggests that large doses per fraction used in SABR may be more effective, but the potential for unexpected toxicity exists, suggesting a need for careful treatment planning and delivery. More safety data will be forthcoming from ongoing clinical trials in this field [101].

\section{Challenges in evaluating new RT technologies}

While classic RCTs remain the gold standard for generating evidence, their applicability for evaluating RT technology has been challenged [102, 103]. The high costs involved, the potential for a learning curve with new technology [104], and ethical concerns with a perceived lack of equipoise between older and new technologies, are all potential impediments. The extended duration of followup required to assess long-term toxicities precludes study completion in a timely manner, and by the time trial results are published, they may be considered invalid due to the interval evolution of technology.

In certain situations, comparative effectiveness research may be a more practical and financially feasible approach for evaluating treatments $[105,106]$. Prospective multicenter registries provide access to large patient numbers and extensive data, which may be integrated and analyzed using a 'big data' approach [107]. Some authors have suggested that dosimetric/complication probability models may help identify patients most likely to benefit from advanced technologies [108], but there remains much uncertainty associated with such models [109]. Similarly, patientreported outcomes (PROs) are being increasingly considered as important clinical endpoints, but PROs can be difficult to select and interpret as they may be influenced by diverse patient factors $[110,111]$. The potential of PROs for evaluating radiotherapy research may be significant, as suggested by a mobile app interface for reporting patient-reported clinical symptoms in advanced NSCLC, that was shown to improve quality of life and survival [112].

By focusing on incremental improvements in technology, radiation oncologists may risk ignoring the fact that clinicians' overall knowledge base and the patient's health are often a more important determinant of patient outcome [113]. For example, a poor forced expiratory volume in one second (FEV1), and large gross tumor volumes, have been associated with a 3-fold increase in early mortality following CRT [114]. Interstitial lung abnormalities, as well as severe chronic obstructive pulmonary disease (COPD), are associated with high all-cause mortality $[115,116]$, and a higher risk of toxicity after CRT $[117,118]$. Other patient factors, including weight loss during the first three weeks of CRT may also profoundly affect survival [119]. An improved understanding of what drives poor outcomes in patients with factors like large tumors and co-morbid illness is needed. If RT delivery is considered in isolation, measures such as the optimization of fractionation schedules for a given patient, or spatiotemporal optimization of radiation dose, are unlikely to result in large improvements in outcomes [120].

Furthermore, more accurate distinction between toxicity related to treatment versus symptoms related to comorbidities is needed. Common COPD symptoms which may be present in patients at baseline can easily be mislabeled as a grade 3 pulmonary toxicity. Simply correlating observed toxicities with OAR dose-volume parameters is insufficient, due to uncertainty in delivered dose [121, 122], and lack of anatomical and functional information. This means that more robust and comprehensive dosimetry reporting is needed in the future.

\section{Conclusion}

Although innovations in treatment planning and delivery have led to more precise and accurate RT delivery, for the majority of NSCLC patients, further improvements in treatment outcomes are likely to come about from an integration of novel biological treatment strategies based on an understanding of cancer and radiotherapy at the molecular level. Understanding which patients may benefit most from a given RT technology, as well as identifying those who are at high risk of treatment toxicity, may help tailor the application of advanced technologies to those most likely to benefit and promote a personalized approach to lung cancer radiotherapy.

\section{Acknowledgements}

Not applicable.

Funding

Not applicable.

Availability of data and material

Not applicable.

\section{Authors' contributions}

All authors contributed to concepts, writing, and final approval of the manuscript.

\section{Competing interests}

SB declares no competing interests.

MD reports grants and personal fees from Varian Medical Systems, personal fees from Brainlab, personal fees from Lilly, outside the submitted work. FL declares no competing interests.

SS reports research funding and speakers honorarium from Varian Medical Systems; advisory board for Lilly Oncology.

Consent for publication

Not applicable.

Ethics approval and consent to participate Not applicable.

\section{Author details}

'Department of Radiation Oncology, Cross Cancer Institute, 11560 University Avenue, Edmonton, AB, Canada T6G 1Z2. ²Department of Radiation Oncology, VU University Medical Center, De Boelelaan 1117, Postbox 70571007 MD Amsterdam, The Netherlands. 
Received: 15 July 2016 Accepted: 2 September 2016 Published online: 06 September 2016

\section{References}

1. Ferlay J, Soerjomataram I, Dikshit R, Eser S, Mathers C, Rebelo M, et al. Cancer incidence and mortality worldwide: sources, methods and major patterns in GLOBOCAN 2012. Int J Cancer. 2015;136:E359-86.

2. Eberhardt WE, De Ruysscher D, Weder W, Le Péchoux C, De Leyn P, Hoffmann $\mathrm{H}$, et al. 2nd ESMO consensus conference in lung cancer: locally advanced stage III non-small-cell lung cancer. Ann Oncol. 2015;26:1573-88.

3. Vansteenkiste J, De Ruysscher D, Eberhardt WEE, Lim E, Senan S, Felip E, et al. Early and locally advanced non-small-cell lung cancer (NSCLC): ESMO clinical practice guidelines for diagnosis, treatment and follow-up. Ann Oncol. 2013;24:vi89-98.

4. Chetty IJ, Devpura S, Liu D, Chen D, Li H, Wen NW, et al. Correlation of dose computed using different algorithms with local control following stereotactic ablative radiotherapy (SABR)-based treatment of non-small-cell lung cancer. Radiother Oncol. 2013;109:498-504

5. Keall PJ, Mageras GS, Balter JM, Emery RS, Forster KM, Jiang SB, et al. The management of respiratory motion in radiation oncology report of AAPM task group 76. Med Phys. 2006;33:3874-900.

6. Chen AB, Neville BA, Sher DJ, Chen K, Schrag D. Survival outcomes after radiation therapy for stage III non-small-cell lung cancer after adoption of computed tomography-based simulation. J Clin Oncol. 2001;29:2305-11.

7. Chun SG, Hu C, Choy H, Komaki RU, Timmerman RD, Schild SE, et al. Comparison of 3-D conformal and intensity modulated radiation therapy outcomes for locally advanced non-small cell lung cancer in NRG oncology/ RTOG 0617. Int J Radiat Oncol Biol Phys. 2015:93 Suppl 3:S1-2.

8. Alhassani A, Chandra A, Chernew ME. The sources of the SGR "hole.". N Engl J Med. 2012;366:289-91.

9. Louie AV, Palma DA, Dahele M, Rodrigues GB, Senan S. Management of early-stage non-small cell lung cancer using stereotactic ablative radiotherapy: controversies, insights, and changing horizons. Radiother Oncol. 2015;114:138-47.

10. Lagerwaard FJ, Haasbeek CJ, Smit EF, Slotman BJ, Senan S. Outcomes of risk-adapted fractionated stereotactic radiotherapy for stage I non-small-cell lung cancer. Int J Radiat Oncol Biol Phys. 2008;70:685-92.

11. Ricardi U, Filippi AR, Guarneri A, Giglioli FR, Ciammella P, Franco P, et al. Stereotactic body radiation therapy for early stage non-small cell lung cancer: results of a prospective trial. Lung Cancer. 2010;68:72-7.

12. Timmerman R, Paulus R, Pass H, Gore E, Edelman M, Galvin J, et al. RTOG 0618: stereotactic body radiation therapy (SBRT) to treat operable early-stage lung cancer patients. J Clin Oncol. 2013;31 suppl 15:7523.

13. Hallqvist A, Lund J, Brustugun O, Bergman B, Bergström P, Signe F, et al. The SPACE study: a randomized phase II trial comparing SBRT and 3DCRT in stage I NSCLC patients; final analysis including HRQL. J Thorac Oncol. 2015;10 Suppl 2:S209.

14. Chang JY, Senan S, Paul MA, Mehran RJ, Louie AV, Balter P, et al. Stereotactic ablative radiotherapy versus lobectomy for operable stage I non-small-cell lung cancer: a pooled analysis of two randomised trials. Lancet Oncol. 2015;16:630-7.

15. Verstegen NE, Oosterhuis JW, Palma DA, Rodrigues G, Lagerwaard FJ, van der Elst A, et al. Stage I-II non-small-cell lung cancer treated using either stereotactic ablative radiotherapy (SABR) or lobectomy by video-assisted thoracoscopic surgery (VATS): outcomes of a propensity score-matched analysis. Ann Oncol. 2013;24:1543-8.

16. Onishi $H$, Shirato $H$, Nagata $Y$, Hiraoka M, Fujino M, Gomi K, et al. Stereotactic body radiotherapy (SBRT) for operable stage I non-small-cell lung cancer: can SBRT be comparable to surgery? Int J Radiat Oncol Biol Phys. 2011:81:1352-8.

17. Lagerwaard FJ, Verstegen NE, Haasbeek CJ, Slotman BJ, Paul MA, Smit EF, et al. Outcomes of stereotactic ablative radiotherapy in patients with potentially operable stage I non-small cell lung cancer. Int J Radiat Oncol Biol Phys. 2012;83:348-53.

18. Nagata $Y$, Hiraoka M, Shibata $T$, Onishi H, Kokubo M, Karasawa K, et al. Prospective trial of stereotactic body radiation therapy for both operable and inoperable T1N0M0 Non-small cell lung cancer: Japan clinical oncology group study JCOG0403. Int J Radiat Oncol Biol Phys. 2015;93:989-96.

19. Hopmans W, Damman OC, Timmermans DR, Haasbeek CJ, Slotman BJ, Senan S. Communicating cancer treatment information using the web: utilizing the patient's perspective in website development. BMC Med Inform Decis Mak. 2014;14:116.

20. Hopmans W, Damman OC, Senan S, Hartemink KJ, Smit EF, Timmermans DR. A patient perspective on shared decision making in stage I non-small cell lung cancer: a mixed methods study. BMC Cancer. 2015;15:959.

21. Dahele M, Palma D, Lagerwaard F, Slotman B, Senan S. Radiological changes after stereotactic radiotherapy for stage I lung cancer. J Thorac Oncol. $2011 ; 6: 1221-8$

22. Huang K, Senthi S, Palma DA, Spoelstra FO, Warner A, Slotman BJ, et al. Highrisk $C T$ features for detection of local recurrence after stereotactic ablative radiotherapy for lung cancer. Radiother Oncol. 2013;109:51-7.

23. Peulen H, Mantel F, Guckenberger M, Belderbos J, Werner-Wasik M, Hope A, Giuliani M, Grills I, Sonke JJ. Validation of high-risk computed tomography features for detection of local recurrence after stereotactic body radiation therapy for early-stage non-small cell lung cancer. Int J Radiat Oncol Biol Phys. 2016. doi:10.1016/j.jijobp.2016.04.003.

24. Mattonen SA, Palma DA, Johnson C, Louie AV, Landis M, Rodrigues G, et al. Detection of local cancer recurrence after stereotactic ablative radiation therapy for lung cancer: physician performance versus radiomic assessment. Int J Radiat Oncol Biol Phys. 2016;94:1121-8.

25. Vansteenkiste J, Crinò L, Dooms C, Douillard JY, Faivre-Finn C, Lim E, et al. 2nd ESMO consensus conference on lung cancer: early-stage non-small-cell lung cancer consensus on diagnosis, treatment and follow-up. Ann Oncol. 2014;25:1462-74.

26. Huang K, Palma D. Follow-up of patients after stereotactic radiation for lung cancer a primer for the nonradiation oncologist. J Thorac Oncol. 2015;10:412-9.

27. Verstegen NE, Lagerwaard FJ, Hashemi SM, Dahele M, Slotman BJ, Senan S. Patterns of disease recurrence after SABR for early stage Non-small-cell lung cancer: optimizing follow-up schedules for salvage therapy. J Thorac Oncol. 2015;10:1195-200

28. Grills IS, Mangona VS, Welsh R, Chmielewski G, Mclnerney E, Martin S, et al. Outcomes after stereotactic lung radiotherapy or wedge resection for stage I non-small-cell lung cancer. J Clin Oncol. 2010;28:928-35.

29. Crabtree TD, Denlinger CE, Meyers BF, El Naqa I, Zoole J, Krupnick AS, et al. Stereotactic body radiation therapy versus surgical resection for stage I non-small cell lung cancer. J Thorac Cardiovasc Surg. 2010;140:377-86.

30. Ward MC, Oh SC, Pham YD, Woody NM, Marwaha G, Videtic GM, et al. Isolated nodal failure after stereotactic body radiotherapy for lung cancer: the role for salvage mediastinal radiotherapy. J Thorac Oncol. 2016. doi:10.1016/j.jtho.2016.05.003

31. Senthi S, Lagerwaard FJ, Haasbeek CJ, Slotman BJ, Senan S. Patterns of disease recurrence after stereotactic ablative radiotherapy for early stage non-small-cell lung cancer: a retrospective analysis. Lancet Oncol. 2012;13: 802-9.

32. Robinson CG, Dewees TA, El Naqa IM, Creach KM, Olsen JR, Crabtree TD, et al. Patterns of failure after stereotactic body radiation therapy or lobar resection for clinical stage I non-small-cell lung cancer. J Thorac Oncol. 2013;8:192-201.

33. Chang JY, Bezjak A, Mornex F. IASLC advanced radiation technology committee stereotactic ablative radiotherapy for centrally located early stage non-small-cell lung cancer: what we have learned. J Thorac Oncol. 2015:10:577-85.

34. Timmerman R, McGarry R, Yiannoutsos C, Papiez L, Tudor K, DeLuca J, et al. Excessive toxicity when treating central tumors in a phase II study of stereotactic body radiation therapy for medically inoperable early-stage lung cancer. J Clin Oncol. 2006;24:4833-9.

35. Senthi S, Haasbeek CJ, Slotman BJ, Senan S. Outcomes of stereotactic ablative radiotherapy for central lung tumours: a systematic review. Radiother Oncol. 2013;106:276-82.

36. Tekatli H, Senan S, Dahele M, Slotman BJ, Verbakel WF. Stereotactic ablative radiotherapy (SABR) for central lung tumors: plan quality and long-term clinical outcomes. Radiother Oncol. 2015;117:64-70.

37. Tekatli $H$, Haasbeek $N$, Dahele M, De Haan P, Verbakel W, Bongers $E$, et al. Outcomes of hypofractionated high-dose radiotherapy in poor-risk patients with "ultracentral" Non-small cell lung cancer. J Thorac Oncol. 2016. doi:10.1016/j.jtho.2016.03.008

38. Huber RM, Fischer R, Hautmann $H$, Pöllinger $B$, Häussinger $K$, Wendt $T$. Does additional brachytherapy improve the effect of external irradiation? a prospective, randomized study in central lung tumors. Int J Radiat Oncol Biol Phys. 1997;38:533-40. 
39. Cannon DM, Mehta MP, Adkison JB, Khuntia D, Traynor AM, Tomé WA, et al Dose-limiting toxicity after hypofractionated dose-escalated radiotherapy in non-small-cell lung cancer. J Clin Oncol. 2013;31:4343-8.

40. Bezjak A, Paulus R, Gaspar L, Timmerman RD, Straube WL, Ryan WF, et al. Primary study endpoint analysis for NRG oncology/RTOG 0813 trial of stereotactic body radiation therapy (SBRT) for centrally located non-small cell lung cancer (NSCLC). Int J Radiat Oncol Biol Phys. 2016;94:5-6.

41. Chang JY, Jabbour SK, De Ruysscher D, Schild SE, Simone 2nd CB, Rengan R, et al. Consensus statement on proton therapy in early-stage and locally advanced non-small cell lung cancer. Int J Radiat Oncol Biol Phys. 2016;95:505-16.

42. Zenke Y, Umemura S, Motegi A, Furukawa K, Kirita K, Matsumoto S, et al. Acute and Progressive Tracheal Stenosis after Proton Beam Therapy with Concurrent Chemotherapy for Non-Small Cell Lung Cancer. J Thorac Oncol. 2016. doi:10.1016/j.jtho.2016.04.011.

43. Dahele M, van Sörnsen de Koste JR, Verbakel WF, Slotman BJ, Senan S. An analysis of planned versus delivered airway doses during stereotactic lung radiotherapy for central tumors. Acta Oncol. 2016;55:934-7.

44. Acharya S, Fischer-Valuck BW, Kashani R, Parikh P, Yang D, Zhao T, et al. Online magnetic resonance image guided adaptive radiation therapy: first clinical applications. Int J Radiat Oncol Biol Phys. 2016;94:394-403.

45. Fallone $B G$. The rotating biplanar linac-magnetic resonance imaging system. Semin Radiat Oncol. 2014:24:200.

46. Lagendijk JJ, van Vulpen M, Raaymakers BW. The development of the MRI linac system for online MRI-guided radiotherapy: a clinical update. J Intern Med. 2016. doi:10.1111/joim.12516.

47. Whelan B, Gierman S, Holloway L, Schmerge J, Keall P, Fahrig R. A novel electron accelerator for MRI-linac radiotherapy. Med Phys. 2016;43:1285.

48. Gazdar AF, Minna JD. Multifocal lung cancers - clonality vs field cancerization and does it matter? J Natl Cancer Inst. 2009;101:541-3.

49. Griffioen GH, Lagerwaard FJ, Haasbeek CJ, Smit EF, Slotman BJ, Senan S. Treatment of multiple primary lung cancers using stereotactic radiotherapy, either with or without surgery. Radiother Oncol. 2013;107:403-8.

50. Murray PF, Spencer $K$, Snee M, Dickinson $P$, Jain P, Clarke $K$, et al. Is stereotactic ablative radiotherapy (SABR) a safe treatment for multiple primary lung cancer (MPLC) non-small cell lung cancer (NSCLC)? Lung Cancer. 2016;91 Suppl 1:S48.

51. Owen D, Olivier KR, Mayo CS, Miller RC, Nelson K, Bauer H, et al. Outcomes of stereotactic body radiotherapy (SBRT) treatment of multiple synchronous and recurrent lung nodules. Radiat Oncol. 2015;10:43.

52. Patchell RA, Tibbs PA, Walsh JW, Dempsey RJ, Maruyama Y, Kryscio RJ, et al. A randomized trial of surgery in the treatment of single metastases to the brain. N Engl J Med. 1990;322:494-500.

53. Ashworth AB, Senan S, Palma DA, Riquet M, Ahn YC, Ricardi U, et al. An individual patient data metaanalysis of outcomes and prognostic factors after treatment of oligometastatic non-small-cell lung cancer. Clin Lung Cancer. 2014;15:346-55.

54. Gomez D, Blumenschein G, Lee J, Hernandez M, Camidge D, Doebele R, et al. Local consolidative therapy (LCT) to improve progression-free survival (PFS) in patients with oligometastatic non-small cell lung cancer (NSCLC) who receive induction systemic therapy (IST): results of a multi-institutional phase II randomized study. J Clin Oncol. 2016:34 Suppl 15:9004

55. Eberhardt WE, Mitchell A, Crowley J, Kondo H, Kim YT, Turrisi 3rd A, et al. The IASLC lung cancer staging project: proposals for the revision of the $M$ descriptors in the forthcoming eighth edition of the TNM classification of lung cancer. J Thorac Oncol. 2015;10:1515-22.

56. Palma DA, Salama JK, Lo SS, Senan S, Treasure T, Govindan R, et al. The oligometastatic state - separating truth from wishful thinking. Nat Rev Clin Oncol. 2014;11:549-57.

57. Besse B, Adjei A, Baas P, Meldgaard P, Nicolson M, Paz-Ares L, et al. 2nd ESMO consensus conference on lung cancer: non-small-cell lung cancer first-line/second and further lines of treatment in advanced disease. Ann Oncol. 2014:25:1475-84

58. Bradley JD, Paulus R, Komaki R, Masters G, Blumenschein G, Schild S, et al. Standard-dose versus high-dose conformal radiotherapy with concurrent and consolidation carboplatin plus paclitaxel with or without cetuximab for patients with stage IIIA or IIIB non-small-cell lung cancer (RTOG 0617): a randomized, two-by-two factorial phase 3 study. Lancet Oncol. 2015;16:187-99.

59. Decker RH, Lynch TJ. Unmet challenges in the use of novel agents in locally advanced non-small-cell lung cancer. J Clin Oncol. 2012;30:582-4.
60. Senan S. Treatment of stage IIIA non-small cell lung cancer: charting the next steps. J Oncol Pract. 2016;12:609-10.

61. Masters GA, Temin S, Azzoli CG, Giaccone G, Baker Jr S, Brahmer JR, et al. Systemic therapy for stage IV non-small-cell lung cancer: American society of clinical oncology clinical practice guideline update. American society of clinical oncology clinical practice. J Clin Oncol. 2015;33:3488-515.

62. Dickhoff C, Dahele M, de Langen AJ, Paul MA, Smit EF, Senan S, et al. Population-based patterns of surgical care for stage IIIA NSCLC in the Netherlands between 2010 and 2013. J Thorac Oncol. 2016;11:566-72

63. Le Péchoux C, Dunant A, Pignon JP, De Ruysscher D, Mornex F, Senan S, et al. Need for a new trial to evaluate adjuvant postoperative radiotherapy in non-small-cell lung cancer patients with N2 mediastinal involvement. J Clin Oncol. 2007;25:e10-1.

64. PORT Meta-analysis Trialists Group. Post-operative radiotherapy in non-small cell lung cancer: systematic review and meta-analysis of individual patient data from nine randomised controlled trials. Lancet. 1998;352:257-63.

65. Lally BE, Zelterman D, Colasanto JM, Haffty BG, Detterbeck FC, Wilson LD. Postoperative radiotherapy for stage II or III non-small-cell lung cancer using the surveillance, epidemiology, and end results database. J Clin Oncol. 2006;24:2998-3006.

66. Robinson CG, Patel AP, Bradley JD, DeWees T, Wagar SN, Morgensztern D, et al. Postoperative radiotherapy for pathologic N2 non-small-cell lung cancer treated with adjuvant chemotherapy: a review of the national cancer data base. J Clin Oncol. 2015;33:870-6.

67. De Ruysscher D, Faivre-Finn C, Nestle U, Hurkmans CW, Le Péchoux C, Price A, et al. European organisation for research and treatment of cancer recommendations for planning and delivery of high-dose, high-precision radiotherapy for lung cancer. J Clin Oncol. 2010;28:5301-10.

68. Grills IS, Hugo G, Kestin LL, Galerani AP, Chao KK, Wloch J, et al. Image-guided radiotherapy via daily online cone-beam CT substantially reduces margin requirements for stereotactic lung radiotherapy. Int J Radiat Oncol Biol Phys. 2008;70:1045-56.

69. Roelofs E, Engelsman M, Rasch C, et al. Results of a multicentric in silico clinical trial (ROCOCO): comparing radiotherapy with photons and protons for non-small cell lung cancer. J Thorac Oncol. 2012;7:165-76.

70. Murshed H, Liu HH, Liao Z, Barker JL, Wang X, Tucker SL, et al. Dose and volume reduction for normal lung using intensity-modulated radiotherapy for advanced-stage non-small-cell lung cancer. Int J Radiat Oncol Biol Phys. 2004;58:1258-67.

71. Blom GJ, Verbakel WF, Dahele M, Hoffmans D, Slotman BJ, Senan S. Improving radiotherapy planning for large volume lung cancer: a dosimetric comparison between hybrid-IMRT and RapidArc. Acta Oncol. 2015;54:427-32.

72. Chen AB, Li L, Cronin A, Schrag D. Comparative effectiveness of intensitymodulated versus 3D conformal radiation therapy among medicare patients with stage III lung cancer. J Thorac Oncol. 2014;9:1788-95.

73. Shirvani SM, Jiang J, Gomez DR, Chang JY, Buchholz TA, Smith BD. Intensity modulated radiotherapy for stage III non-small cell lung cancer in the United States: predictors of use and association with toxicities. Lung Cancer. 2013;82:252-9.

74. Sher DJ, Koshy M, Liptay MJ, Fidler MJ. Influence of conformal radiotherapy technique on survival after chemoradiotherapy for patients with stage III nonsmall cell lung cancer in the national cancer data base. Cancer. 2014;120:2060-8.

75. Ling DC, Hess CB, Chen AM, Daly ME. Comparison of toxicity between intensity-modulated radiotherapy and 3-dimensional conformal radiotherapy for locally advanced non-small-cell lung cancer. Clin Lung Cancer. 2016;17(1):18-23.

76. Harris JP, Murphy JD, Hanlon AL, Le QT, Loo Jr BW, Diehn M. A populationbased comparative effectiveness study of radiation therapy techniques in stage III non-small cell lung cancer. Int J Radiat Oncol Biol Phys. 2014:88:872-84.

77. Jegadeesh N, Liu Y, Gillespie T, Fernandez F, Ramalingam S, Mikell J, et al. Evaluating Intensity-Modulated Radiation Therapy in Locally Advanced Non-Small-Cell Lung Cancer: Results From the National Cancer Data Base. Clin Lung Cancer. 2016. doi:10.1016/j.cllc.2016.01.007.

78. Senan S, Brade A, Wang LH, Vansteenkiste J, Dakhil S, Biesma B, et al. PROCLAIM: randomized phase III trial of pemetrexed-cisplatin or etoposide-cisplatin plus thoracic radiation therapy followed by consolidation chemotherapy in locally advanced nonsquamous non-small-cell lung cancer. J Clin Oncol. 2016;34:953-62.

79. Ahn JS, Ahn YC, Kim JH, Lee CG, Cho EK, Lee KC. Multinational randomized phase III trial with or without consolidation chemotherapy 
using docetaxel and cisplatin after concurrent chemoradiation in inoperable stage III non-small-cell lung cancer: KCSG-LU05-04. J Clin Oncol. 2015;33:2660-6.

80. Movsas B, Hu C, Sloan J, Bradley J, Komaki R, Masters G, et al. Quality of life analysis of a radiation dose-escalation study of patients with non-small-cell lung cancer: a secondary analysis of the radiation therapy oncology group 0617 randomized clinical trial. JAMA Oncol. 2016;2:359-67.

81. Eaton BR, Pugh SL, Bradley JD, Masters G, Kavadi VS, Narayan S, et al. Institutional enrollment and survival among NSCLC patients receiving chemoradiation: NRG oncology radiation therapy oncology group (RTOG) 0617. J Natl Cancer Inst. 2016. doi:10.1093/jnci/djw034.

82. Tucker SL, Liu A, Gomez D, Tang LL, Allen P, Yang J, et al. Impact of heart and lung dose on early survival in patients with non-small cell lung cance treated with chemoradiation. Radiother Oncol. 2016. doi:10.1016/j.radonc. 2016.04.025.

83. Verma V, Mishra MV, Mehta MP. A systematic review of the cost and cost-effectiveness studies of proton radiotherapy. Cancer. 2016;122:1483-501.

84. Lievens Y, Verhaeghe N, De Neve W, Madani I, Vanderstraeten B, Verstraete $J$, et al. Proton radiotherapy for locally-advanced non-small cell lung cancer, a cost-effective alternative to photon radiotherapy in Belgium? J Thorac Oncol. 2013;8 suppl 2:S839-40.

85. Chang JY, Zhang X, Wang X, Kang Y, Riley B, Bilton S, et al. Significant reduction of normal tissue dose by proton radiotherapy compared with three-dimensional conformal or intensity-modulated radiation therapy in stage I or stage III non-small-cell lung cancer. Int J Radiat Oncol Biol Phys. 2006;65:1087-96.

86. Register SP, Zhang X, Mohan R, Chang JY. Proton stereotactic body radiation therapy for clinically challenging cases of centrally and superiorly located stage I non-small-cell lung cancer. Int J Radiat Oncol Biol Phys. 2011;80:1015-22.

87. Zhang X, Li Y, Pan X, Xiaoqiang L, Mohan R, Komaki R, et al. Intensitymodulated proton therapy reduces the dose to normal tissue compared with intensity-modulated radiation therapy or passive scattering proton therapy and enables individualized radical radiotherapy for extensive stage IIIB non-small-cell lung cancer: a virtual clinical study. Int J Radiat Oncol Biol Phys. 2010;77:357-66.

88. Albertini F, Bolsi A, Lomax AJ, Rutz HP, Timmerman B, Goitein G. Sensitivity of intensity modulated proton therapy plans to changes in patient weight. Radiother Oncol. 2008;86:187-94.

89. Sejpal S, Komaki R, Tsao A, Chang JY, Liao Z, Wei X, et al. Early findings on toxicity of proton beam therapy with concurrent chemotherapy for nonsmall cell lung cancer. Cancer. 2011;117:3004-13.

90. Liao Z, Lee J, Komaki R, Gomez D, O'Reilly M, Allen P, et al. A Bayesian randomisation trial of IMRT vs. PSPT for locally advanced non-small cell lung carcinoma. Radiother Oncol. 2016;119 Suppl 1:S65.

91. Liao Z, Lee J, Komaki R, Gomez D, O'Reilly M, Allen P, et al. Bayesian randomized trial comparing intensity modulated radiation therapy versus passively scattered proton therapy for locally advanced non-small cell lung cancer. J Clin Oncol. 2016;34 suppl 15:8500.

92. Zhang J, Gold KA, Lin HY, Swisher SG, Xing Y, Lee JJ, et al. Relationship between tumor size and survival in non-small cell lung cancer (NSCLC): an analysis of the surveillance, epidemiology, and end results (SEER) registry. J Thorac Oncol. 2015;10:682-90.

93. Basaki $\mathrm{K}$, Abe $\mathrm{Y}$, Aoki M, Kondo H, Hatayama Y, Nakaji S. Prognostic factors for survival in stage III non-small-cell lung cancer treated with definitive radiation therapy: impact of tumor volume. Int J Radiat Oncol Biol Phys. 2006;64:449-54

94. Wiersma TG, Dahele M, Verbakel WF, van de Ven PM, de Haan PF, Smit EF, et al. Concurrent chemoradiotherapy for large-volume locally-advanced non-small cell lung cancer. Lung Cancer. 2013;80:62-7.

95. Sullivan R, Peppercorn J, Sikora K, Zalcberg J, Meropol NJ, Amir E, et al. Delivering affordable cancer care in high-income countries. Lancet Oncol. 2011;12:933-80

96. Atun R, Jaffray DA, Barton MB, Bray F, Baumann M, Vikram B, et al. Expanding global access to radiotherapy. Lancet Oncol. 2015;16:1153-86.

97. Salama AK, Postow MA, Salama JK. Irradiation and immunotherapy: from concept to the clinic. Cancer. 2016;122:1659-71.

98. Reynders K, Illidge T, Siva S, Chang JY, De Ruysscher D. The abscopal effect of local radiotherapy: using immunotherapy to make a rare event clinically relevant. Cancer Treat Rev. 2015;41:503-10.
99. Whiteside TL, Demaria S, Rodriguez-Ruiz ME, Zarour HM, Melero I. Emerging opportunities and challenges in cancer immunotherapy. Clin Cancer Res. 2016;22:1845-55.

100. Kim JM, Chen DS. Immune escape to PD-L1/PD-1 blockade: seven steps to success (or failure). Ann Oncol. 2016. doi:10.1093/annonc/mdw217.

101. Johnson C, Jagsi R. The promise of the abscopal effect and the future of trials combining immunotherapy and radiation therapy. Int J Radiat Oncol Biol Phys. 2016;95:1254-6.

102. van Loon J, Grutters J, Macbeth F. Evaluation of novel radiotherapy technologies: what evidence is needed to assess their clinical and cost effectiveness, and how should we get it? Lancet Oncol. 2012;13:e169-77.

103. IOM (Institute of Medicine). Delivering high-quality cancer care: charting a new course for a system in crisis. Washington, DC: The National Academies Press; 2013.

104. Bonastre J, Noel E, Chevalier J, Gerard JP, Lefkopoulos D, Bourhis J, et al. Implications of learning eff ects for hospital costs of new health technologies: the case of intensity modulated radiation therapy. Int J Technol Assess Health Care. 2007;23:248-54.

105. Lyman GH, Levine M. Comparative effectiveness research in oncology: an overview. J Clin Oncol. 2012;30:4181-4.

106. Chavez-MacGregor M, Giordano SH. Randomized clinical trials and observational studies: is there a battle? J Clin Oncol. 2016;34:772-3.

107. Kessel K, Combs S. Review of developments in electronic, clinical data collection, and documentation systems over the last decade - are we ready for big data in routine health care? Front Oncol. 2016. doi:10.3389/fonc. 2016.00075

108. Langendijk JA, Lambin P, De Ruysscher D, Widder J, Bos M, Verheij M. Selection of patients for radiotherapy with protons aiming at reduction of side effects: the model-based approach. Radiother Oncol. 2013;107:267-73.

109. Bentzen SM, Constine LS, Deasy JO, Eisbruch A, Jackson A, Marks LB, et al. Quantitative analyses of normal tissue effects in the clinic (QUANTEC): an introduction to the scientific issues. Int J Radiat Oncol Biol Phys. 2010;76 Suppl 3:S3-9.

110. Mukesh MB, Qian W, Wilkinson JS, Dorling L, Barnett GC, Moody AM, et al. Patient reported outcome measures (PROMs) following forward planned field-in field IMRT: results from the Cambridge breast IMRT trial. Radiother Oncol. 2014;111:270-5.

111. Mukesh MB, Qian W, Wah Hak CC, Wilkinson JS, Barnett GC, Moody AM, et al. The Cambridge breast intensity-modulated radiotherapy trial: comparison of clinician- versus patient-reported outcomes. Clin Oncol (R Coll Radiol). 2016;28:354-64.

112. Denis F, Lethrosne C, Pourel N, Molinier O, Pointreau Y, Domont J, et al. Overall survival in patients with lung cancer using a web-application-guided follow-up compared to standard modalities: results of phase III randomized trial. J Clin Oncol. 2016:34 suppl 15:9006.

113. Glatstein E. Distinguishing "controversy" from conflict of interest: the wrong image for radiation oncology. Int J Radiat Oncol Biol Phys. 2010;76:1283-4.

114. Warner A, Dahele M, Hu B, Palma DA, Senan S, Oberije C, et al. Factors associated with early mortality in patients treated with concurrent chemoradiation therapy for locally advanced non-small cell lung cancer. Int J Radiat Oncol Biol Phys. 2016;94:612-20.

115. Putman RK, Hatabu H, Araki T, Gudmundsson G, Gao W, Nishino M, et al. Association between interstitial lung abnormalities and All-cause mortality. JAMA. 2016;315:672-81.

116. Suissa S, Dell'Aniello S, Ernst P. Long-term natural history of chronic obstructive pulmonary disease: severe exacerbations and mortality. Thorax. 2012;67:957-63.

117. Ohe Y, Yamamoto S, Suzuki K, Hojo F, Kakinuma R, Matsumoto T, et al. Risk factors of treatment-related death in chemotherapy and thoracic radiotherapy for lung cancer. Eur J Cancer. 2001;37:54-63.

118. Donington J, Ferguson M, Mazzone P, Handy Jr J, Schuchert M, Fernando H, et al. American college of chest physicians and society of thoracic surgeons consensus statement for evaluation and management for high-risk patients with stage I non-small cell lung cancer. Chest. 2012;142:1620-35.

119. Sanders KJ, Hendriks LE, Troost EG, Bootsma GP, Houben RM, Schols AM, et al. Early weight loss during chemoradiotherapy Has a detrimental impact on outcome in NSCLC. J Thorac Oncol. 2016;11:873-9.

120. Kim M, Craft DL. Within the next five years, most radiotherapy treatment schedules will be designed using spatiotemporal optimization. Med Phys. 2016;43:2009-11. 
121. Webb S. Does elastic tissue intrafraction motion with density changes forbid motion-compensated radiotherapy? Phys Med Biol. 2006;51:1449-62.

122. Li HS, Zhong H, Kim J, Glide-Hurst C, Gulam M, Nurushev TS, et al. Direct dose mapping versus energy/mass transfer mapping for $4 \mathrm{D}$ dose accumulation: fundamental differences and dosimetric consequences. Phys Med Biol. 2014;59:173-88.

123. Best MG, Sol N, Kooi I, Tannous J, Westerman BA, Rustenburg F, et al. RNA-Seq of tumor-educated platelets enables blood-based Pan-cancer, multiclass, and molecular pathway cancer diagnostics. Cancer Cell. 2015;28:666-76,

124. Huang J, Logue AE, Ostroff JS, Park BJ, McCabe M, Jones DR, et al. Comprehensive long-term care of patients with lung cancer: development of a novel thoracic survivorship program. Ann Thorac Surg. 2014;98:955-61.

125. van Meerbeeck JP, Kramer GW, Van Schil PE, Legrand C, Smit EF, Schramel $F$, et al. Randomized controlled trial of resection versus radiotherapy after induction chemotherapy in stage IIIA-N2 non-small-cell lung cancer. J Natl Cancer Inst. 2007:99:442-50

126. Albain KS, Swann RS, Rusch WW, Turrisi 3rd AT, Shepherd FA, Smith C, et al. Radiotherapy plus chemotherapy with or without surgical resection for stage III non-small-cell lung cancer: a phase III randomised controlled trial. Lancet. 2009;374:379-86.

127. Eberhardt WE, Pöttgen C, Gauler TC, Friedel G, Veit S, Heinrich V, et al. Phase III study of surgery versus definitive concurrent chemoradiotherapy boost in patients with resectable stage IIIA(N2) and selected IIIB non-small-cell lung cancer after induction chemotherapy and concurrent chemoradiotherapy (ESPATUE). J Clin Oncol. 2015:33:4194-201.

128. Pless M, Stupp R, Ris HB, Stahel RA, Weder W, Thierstein S, et al. Induction chemoradiation in stage IIIA/N2 non-small-cell lung cancer: a phase 3 randomised trial. Lancet. 2015;386:1049-56.

129. Curran Jr WJ, Paulus R, Langer CJ, Komaki R, Lee JS, Hauser S, et al. Sequential vs. concurrent chemoradiation for stage III non-small cell lung cancer: randomized phase III trial RTOG 9410. J Natl Cancer Inst. 2011:103:1452-60.

130. Aupérin A, Le Péchoux C, Rolland E, Curran WJ, Furuse K, Fournel P, et al. Meta-analysis of concomitant versus sequential radiochemotherapy in locally advanced non-small-cell lung cancer. J Clin Oncol. 2010;28:2181-90.

\section{Submit your next manuscript to BioMed Central and we will help you at every step:}

- We accept pre-submission inquiries

- Our selector tool helps you to find the most relevant journal

- We provide round the clock customer support

- Convenient online submission

- Thorough peer review

- Inclusion in PubMed and all major indexing services

- Maximum visibility for your research

Submit your manuscript at www biomedcentral.com/submit 